\title{
The anticancer effect and mechanism of $\alpha$-hederin on breast cancer cells
}

\author{
LIN CHENG $^{1 *}$, TIAN-SONG XIA $^{1 *}$, YI-FEN WANG $^{3 *}$, WENBIN ZHOU $^{1}$, XIU-QING LIANG ${ }^{1}$, \\ JIN-QIU XUE ${ }^{1}$, LIANG SHI ${ }^{1}$, YING WANG ${ }^{1}$, QIANG DING $^{1}$ and MINHAI WANG ${ }^{2}$ \\ ${ }^{1}$ Jiangsu Breast Disease Center, The First Affiliated Hospital with Nanjing Medical University, Nanjing 210029; \\ ${ }^{2}$ Department of General Surgery, The First Affiliated Yijishan Hospital with Wannan Medical College, \\ Wuhu 241001; ${ }^{3}$ State Key Laboratory of Phytochemistry and Plant Resources in West China, \\ Kunming Institute of Botany, Chinese Academy of Sciences, Kunming 650204, P.R. China
}

Received February 14, 2014; Accepted April 24, 2014

DOI: $10.3892 /$ ijo.2014.2449

\begin{abstract}
Natural plant products occupy a very important position in the area of cancer chemotherapy. Many triterpenoid saponins have been proved as potential agents for chemoprevention and therapy of breast cancer. $\alpha$-hederin, a monodesmosidic triterpenoid saponin distributed in Hedera or Nigella species, displays many biological activities. It is increasingly investigated for its promising anticancer potential since it has been shown to have cytotoxicity against several types of cancer cells. However, studies of $\alpha$-hederin on breast cancer are limited, most of which focus on biological activity, while the mechanisms have not been widely reported yet. Previously, we purified and identified $\alpha$-hederin from Clematis ganpiniana, a herb used in traditional Chinese medicine with antitumor action. In the present study, $\alpha$-hederin showed strong inhibitory activity on the growth of breast cancer cells and induced apoptosis in these cells. $\alpha$-hederin induced depolarization of mitochondrial membrane potential which released Apaf-1 and cytochrome $c$ from the intermembrane space into the cytosol, where they promoted caspase- 3 and caspase- 9 activation. This is the first report on the growth inhibition and pro-apoptotic effects of $\alpha$-hederin on breast cancer cells and the relative apoptosis pathways. It implied that triterpenoid saponin $\alpha$-hederin could be a promising candidate for chemotherapy of breast cancer.
\end{abstract}

Correspondence to: Dr Qiang Ding, Jiangsu Breast Disease Center, The First Affiliated Hospital with Nanjing Medical University, 300 Guangzhou Road, Nanjing 210029, P.R. China

E-mail: dingqiang@njmu.edu.cn

Dr Minhai Wang, Department of General Surgery, The First Affiliated Yijishan Hospital with Wannan Medical College, 2 West Zheshan Road, Wuhu 241001, P.R. China

E-mail:wangmh0410@sina.com

${ }^{*}$ Contributed equally

Key words: $\alpha$-hederin, breast cancer, apoptosis, mechanism, mitochondria

\section{Introduction}

Breast cancer is the most frequently diagnosed and the leading cause of cancer related death in women (1). A variety of drugs have been developed to treat breast cancer, however, drug resistance often occurs, and unexpected side-effects are common (2). Thus, novel chemotherapies that overcome drug resistance and improve patient outcomes are urgently needed. Using compounds from natural plants as potential cancer preventive and/or therapeutic agents has become a fascinating strategy $(3,4)$. Identification and investigation of active components from natural plants are important for assessing their potential for clinical use. A large number of components purified from herbs have been used to treat various cancers including breast cancer. For example, paclitaxel (Taxol), a natural chemotherapeutic drug isolated from the bark of the pacific yew, is currently used widely for treating breast cancer (5). Therefore, development of new therapeutic agents from natural source has great promise for breast cancer treatment.

We have purified and identified four kinds of triterpenoids derivatives from Clematis ganpiniana. They showed cytotoxicity against breast cancer cells (6). One of them was $\alpha$-hederin, which belonged to triterpenoid saponins. Triterpenoid saponins are an important class of natural products and distributed widely in the plant kingdom $(7,8)$. Several excellent studies provided an overview of the triterpenoids as potential agents for chemoprevention and therapy of breast cancer $(9,10)$.

$\alpha$-hederin, a monodesmosidic triterpenoid saponin distributed in Hedera or Nigella species displays many biological activities such as anti-viral activity (11); anti-inflammatory activity (12); anti-oxidant activity (13); anti-leishmanial activity (14) and anti-spasmodic activity (15).Moreover, $\alpha$-hederin is increasingly investigated for its promising anticancer potential since it revealed cytotoxicity against various cancer cell lines such as lung carcinoma, larynx epidermoid carcinoma, colon adenocarcinoma and pancreas carcinoma (16-20) and in vivo tumors (21-23). It has been suggested that $\alpha$-hederin exerted its cytotoxic activity by promoting apoptosis and/or membrane alterations $(24,25)$, however, the molecular and cellular mechanisms are far from being fully elucidated. Moreover, reports on 
the anti-breast cancer acivity of $\alpha$-hederin are scarce, most of which focus on biological activity, while the mechanisms have not been widely reported yet.

$\alpha$-hederin have been previously reported to inhibit growth and induce apoptosis of breast cancer cells (6), however, further effects and mechanisms of $\alpha$-hederin on breast cancer is currently unavailable. In this study, we evaluated effects of $\alpha$-hederin on growth and apoptosis of various human breast cancer cell lines, and explored the underlying mechanisms.

\section{Materials and methods}

Drug preparations. Protocols of the collection, storage, extraction of the plant material of Clematis ganpiniana, the methods of the purification and analysis of the $\alpha$-hederin were described in a previous study (6).

Cell culture. The human breast cancer cell lines MCF-7 and MDA-MB-231 were obtained from American Type Culture Collection (Manassas, VA, USA) and incubated in a humidified atmosphere of $5 \% \mathrm{CO}_{2}$ in air at $37^{\circ} \mathrm{C}$ and fed with the culture medium of high glucose Dulbecco's modified Eagle's medium, supplemented with $10 \%$ fetal bovine serum, $1 \%$ penicillin-streptomycin solution. For routine passages, cultures were split $1: 3$ when they reached $80-90 \%$ confluence generally every 2-3 days. All experiments were performed on exponentially growing cells. MCF-7 and MDA-MB-231 cells are widely used in studies on human breast cancer. In this study, we used these two cell lines to evaluate the growth inhibition and explore the underlying molecular mechanisms of $\alpha$-hederin.

MTT assay. The MTT assay was used to measure the inhibition of growth by $\alpha$-hederin in breast cancer cell lines. Briefly, $5 \times 10^{3}$ cells were seeded into a 96-well plate in triplicate and $8 \mathrm{~h}$ later $\alpha$-hederin was added into the wells at the indicated final concentrations $(0.08,0.4,2$ and $10 \mu \mathrm{g} / \mathrm{ml})$, while cells cultured in medium with $0.05 \%$ DMSO as a negative control. After incubation with $\alpha$-hederin for 12,24 and $48 \mathrm{~h}$, the medium in each well was replaced with $20 \mu \mathrm{l}$ of MTT at $5 \mathrm{mg} / \mathrm{ml}$ final concentration, and $4 \mathrm{~h}$ later $150 \mu \mathrm{l} \mathrm{DMSO} /$ well was added to dissolve the formed violet formazan crystals within metabolically viable cells. The plates were incubated at room temperature for $15 \mathrm{~min}$ and then read at $490 \mathrm{~nm}$ with a microplate reader (Tecan, Grödig, Austria). The percentage of growth inhibition was calculated as (OD of the control - OD of the experiment samples)/OD of the control x 100.

Apoptosis analysis by flow cytometry. After exposure to $2 \mu \mathrm{g} / \mathrm{ml} \alpha$-hederin for 6,12 and $24 \mathrm{~h}$, breast cancer cells were washed twice with PBS at $4^{\circ} \mathrm{C}$, resuspended in stain containing Annexin V-FITC and propidium iodide (PI) for 15 min incubation on ice, and analyzed with FACSAria flow cytometer (Becton-Dickinson, San Jose, CA, USA) using FACSDiva software. Approximately $10^{5}$ cells were analyzed for each treatment.

Measurement of the mitochondrial membrane potential $(\Delta \Psi m)$ with $J C-1$. The mitochondrial membrane potential was measured according to the manufacturer's instruction with JC-1. After exposure to $2 \mu \mathrm{g} / \mathrm{ml} \alpha$-hederin for 6,12

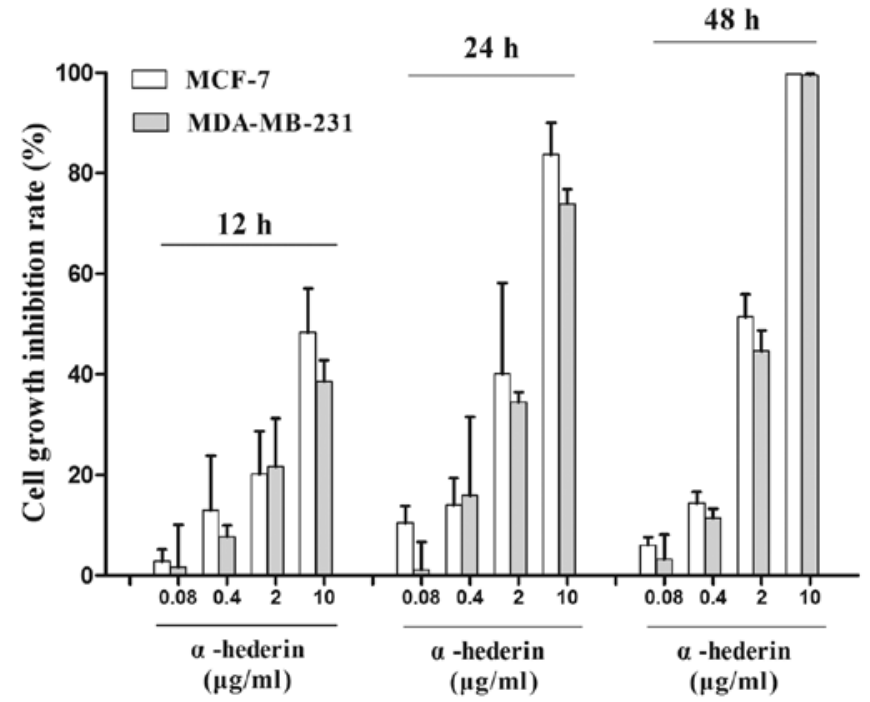

Figure 1. $\alpha$-hederin inhibits growth of breast cancer cells. MTT assay of MCF-7 and MDA-MB-231 cells treated with various concentrations of $\alpha$-hederin for 12,24 and $48 \mathrm{~h}$. Data are mean \pm standard error of mean (SEM) of three independent experiments.

and $24 \mathrm{~h}$, cells were washed twice with PBS, incubated in the working solution of $2 \mu \mathrm{g} / \mathrm{ml} \mathrm{JC}-1$ for $30 \mathrm{~min}$ at $37^{\circ} \mathrm{C}$ in $5 \% \mathrm{CO}_{2}$ atmosphere, and observed with Zeiss LSM 5 Live confocal microscope (Carl Zeiss, Jena, Germany). The fluorescence was measured at an excitation:emission of 485/538 for green monomers and at an excitation:emission of 485/590 for red aggregates. Valinomycin was used at a concentration of $0.1 \mu \mathrm{M}$ as a positive control for depolarization of the $\Delta \Psi \mathrm{m}$.

Measurement of cellular caspase-3 and -9 activity. Caspase-3 and -9 activity was quantified by measuring cleavage of the colorimetric peptides RED-DEVD-FMK and RED-LEHD-FMK, respectively (BioVision, Palo Alto, CA, USA). Briefly, at the end of designated treatment ( $24 \mathrm{~h}$ of exposure to $2 \mu \mathrm{g} / \mathrm{ml} \alpha$-hederin), equal number of control or treated cells were incubated with RED-DEVD-FMK and RED-LEHD-FMK, respectively $(2 \mu \mathrm{g} / \mathrm{ml})$ for $20 \mathrm{~min}$ at $37^{\circ} \mathrm{C}$ in $5 \% \mathrm{CO}_{2}$ atmosphere, then washed twice by PBS and analyzed with FACSAria flow cytometer. For the caspase inhibition study, the cells were pre-incubated with inhibitors: z-DEVD-FMK and z-LEHD-FMK (respectively, caspase-3 and -9 inhibitors) $1 \mathrm{~h}$ before $\alpha$-hederin treatment.

Western blot analysis. MCF-7 and MDA-MB-231 cells were seeded at $1 \times 10^{6}$ cells in $100-\mathrm{mm}^{2}$ dishes. Cells were treated in complete medium with $\alpha$-hederin for 6,12 and $24 \mathrm{~h}$. After treatment, adherent cells were gently scraped from the plates into the medium containing floating cells to obtain all the cells. Cells were then centrifuged, washed in PBS, lysed in ice-cold lysis buffer containing phosphatase inhibitor cocktail and protease inhibitor cocktail (Boehringer, Mannheim, Germany) to obtain total protein. Protein concentrations were determined using the Bradford method.

Apaf-1 and cytochrome $c$ in mitochondrial fraction were analyzed by isolation of mitochondrial protein using the Cell Mitochondria Isolation kit (Beyotime Institute of Biotechnology, 
A

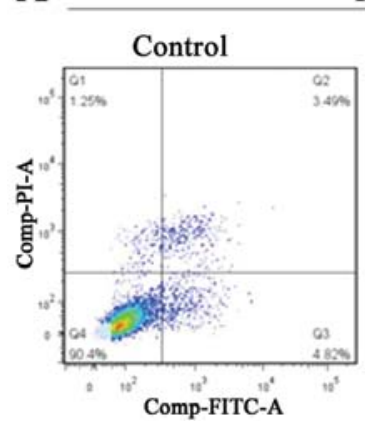

$12 \mathrm{~h}$

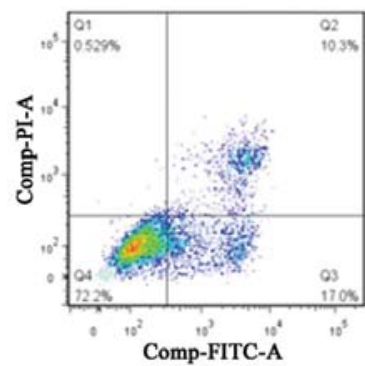

MCF-7

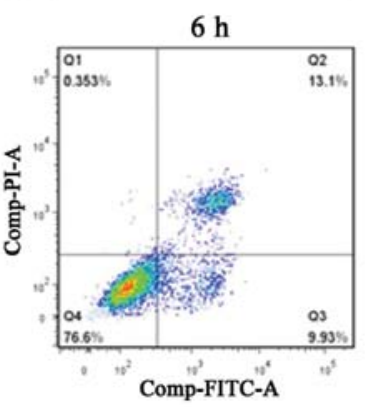

$24 \mathrm{~h}$

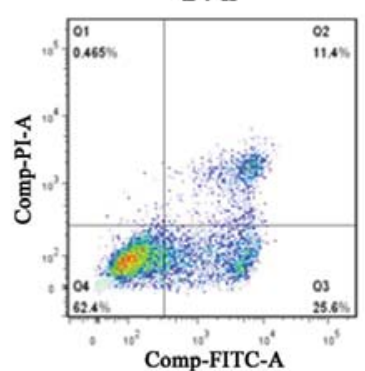

B

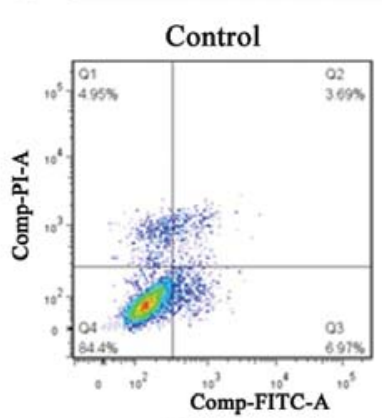

$12 \mathrm{~h}$

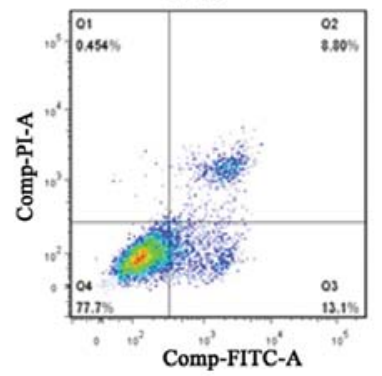

MDA-MB-231

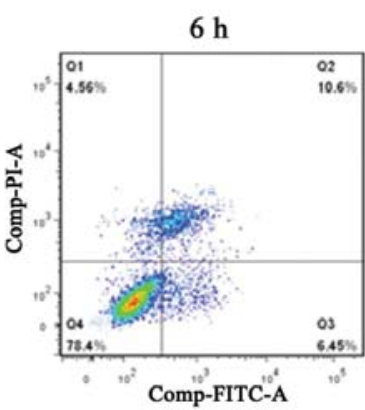

$24 \mathrm{~h}$

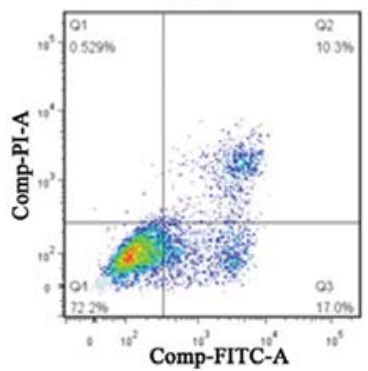

C

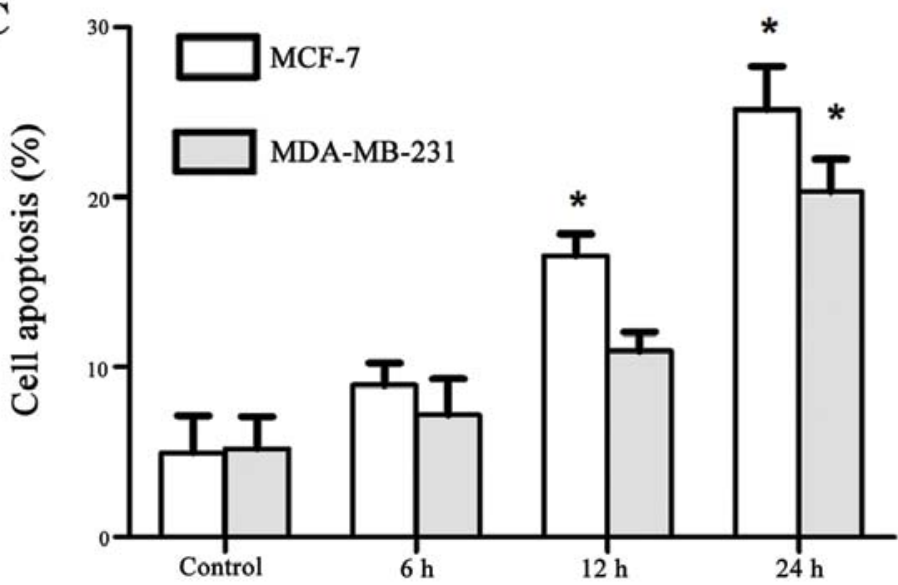

Figure 2. $\alpha$-hederin induced apoptosis in breast cancer cells. (A and B) The apoptosis rate of MCF-7 and MDA-MB-231 cells measured by flow cytometry. $\alpha$-hederin induced early apoptosis in MCF-7 and MDA-MB-231 cells. (C) Early apoptosis rate of MCF-7 and MDA-MB-231 cells treated with $\alpha$-hederin of three independent experiments are shown in column statistics. Data are mean \pm SEM of three independent experiments. ${ }^{*} p<0.05$ vs. $\alpha$-hederin-untreated group.

Beijing,China).Briefly, after exposure, MCF-7 and MDA-MB-231 cells were harvested and centrifuged at $800 \mathrm{x}$ g at $4^{\circ} \mathrm{C}$ for $10 \mathrm{~min}$. The pellets were added with $20 \mathrm{mM} \mathrm{N}$-2-hydroxyethylpiperazineN0-20-ethanesulfonic acid (HEPES) buffer containing protease inhibitor cocktail and disrupted with a glass tissue grinder. Homogenates were centrifuged at $800 \mathrm{x} \mathrm{g}$ at $4^{\circ} \mathrm{C}$ for $10 \mathrm{~min}$, and the resulting supernatants were transferred to $0.5 \mathrm{ml}$ conical tubes, and further centrifuged at $10,000 \times \mathrm{g}$ at $4^{\circ} \mathrm{C}$ for $20 \mathrm{~min}$. The final pellets, containing the mitochondrial fraction, were analyzed for protein content using the Bradford method.

Cell lysates were electrophoresed through 10-12\% SDS-PAGE gel, and transferred to PVDF membranes, which were activated in methanol. The blots were probed or reprobed with antibodies. GAPDH was used to normalize for protein loading. The membranes were probed using ECL and autoradiographed. The intensity of the bands was determined using densitometric analysis. The primary antibodies used were puri- fied mouse anti-human apoptotic protease activating factor-1 (Apaf-1) and cytochrome $c$, purchased from BD Bioscience. $\beta$-actin was from Sigma. Anti-mouse secondary antibodies were from Cell Signaling Technology. The antibodies were diluted according to the manufacturer's instructions.

Statistical analysis. The data were analyzed using the SPSS 20.0 software. For all the measurements, oneway ANOVA followed by Bonferroni test was used to assess the statistical significance of difference between control and groups-treated. A statistically significant difference was considered at the level of $\mathrm{p}<0.05$.

\section{Results}

$\alpha$-hederin inhibits the growth of breast cancer cells. In this study, two breast cancer cell lines MCF-7, MDA-MB-231, were 

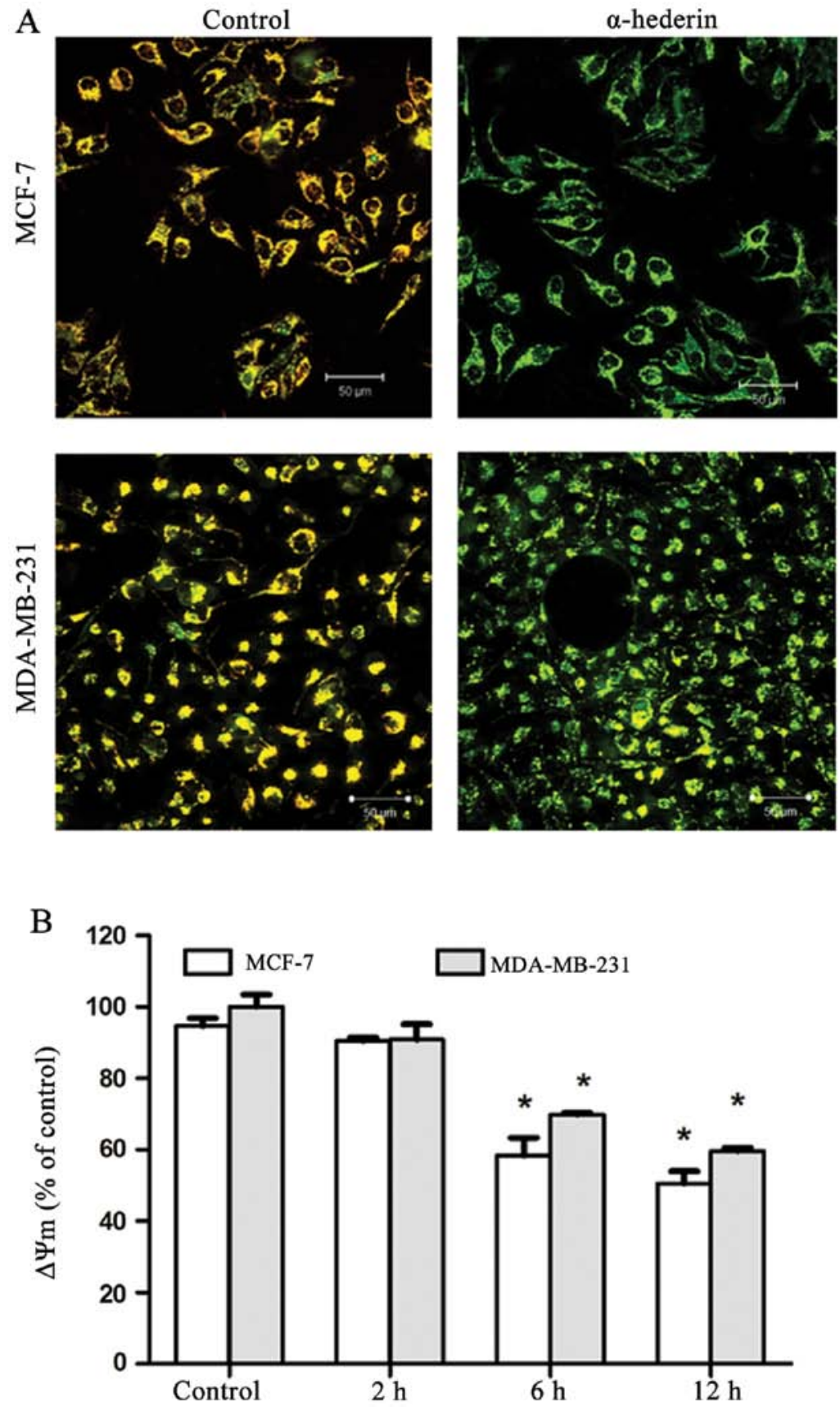

Figure 3. $\alpha$-hederin reduced the mitochondrial membrane potential of MCF-7 and MDA-MB-231 cells. (A) Effects of $\alpha$-hederin on the mitochondrial depolarization in MCF-7 and MDA-MB-231 cells. After the application of DR $\beta-\mathrm{H}$, JC-1 fluorescence shifted from red-orange to greenish yellow, which indicated the depolarization of mitochondrial membrane potential. (B) Quantification of mitochondrial membrane potential $\Delta \Psi \mathrm{m}$ (\% of control) was expressed as a ratio of J-aggregate to JC-1 monomer (red: green) fluorescence intensity. $\Delta \Psi \mathrm{m}$ (\% of control) of cells treated with $\alpha$-hederin for 2, 6 and $12 \mathrm{~h}$ of three independent experiments are shown in column statistics. ${ }^{*} \mathrm{p}<0.05$ vs. $\alpha$-hederin-untreated group.

used. The inhibitory rate of growth was determined by MTT assay. $\alpha$-hederin showed inhibition in the two breast cancer cell lines which were statistically significant compared to the negative control $(\mathrm{p}<0.05)$ (Fig. 1).

$\alpha$-hederin induces apoptosis in breast cancer cells. The apoptosis rate was measured by flow cytometry. MCF-7 and MDA-MB-231 treated with $2 \mu \mathrm{g} / \mathrm{ml} \alpha$-hederin for indicated times $(6,12$ and $24 \mathrm{~h}$ ) were first double-stained with Annexin V and PI, and then analyzed by flow cytometry. In cells treated with $\alpha$-hederin, we detected a major increase in the Annexin $\mathrm{V}^{+} / \mathrm{PI}$ fraction (regarded as early apoptotic) subpopulations. After incubated with $2 \mu \mathrm{g} / \mathrm{ml} \alpha$-hederin for $24 \mathrm{~h}$, early apoptosis rate of MCF-7 and MDA-MB-231 cells were significantly increased up to 25.6 and $17.0 \%$, respectively (Fig. 2A and B). Early apoptosis rate of cells treated with $\alpha$-hederin of three independent experiments are shown in column statistics (Fig. 2C).

$\alpha$-hederin affects the mitochondrial membrane potential $(\Delta \Psi m)$ of breast cancer cells. MCF-7 and MDA-MB-231 cells 
A
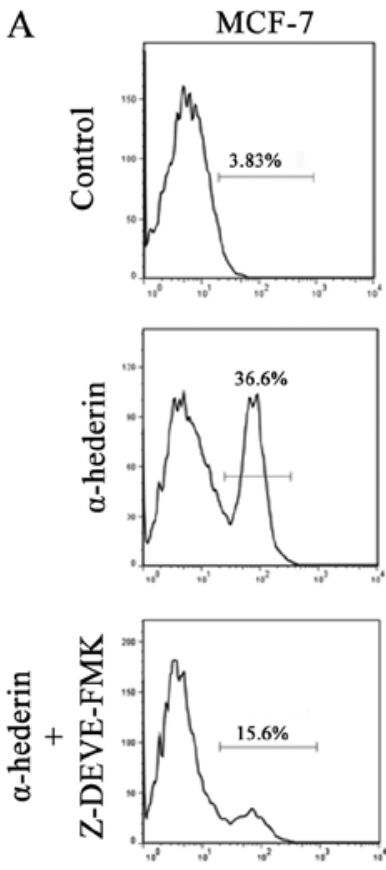

Caspase 3
MDA-MB-231
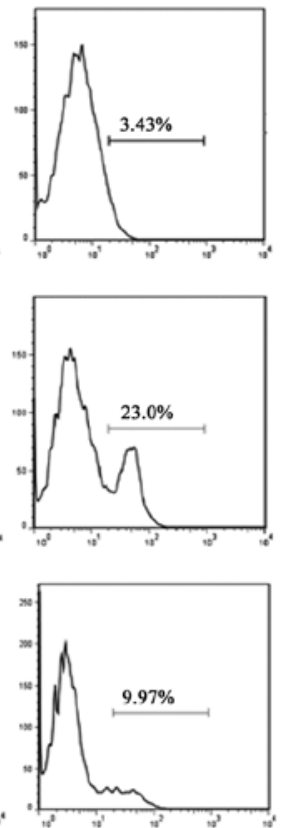

Caspase 3

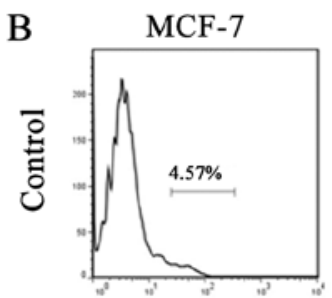

MDA-MB-231
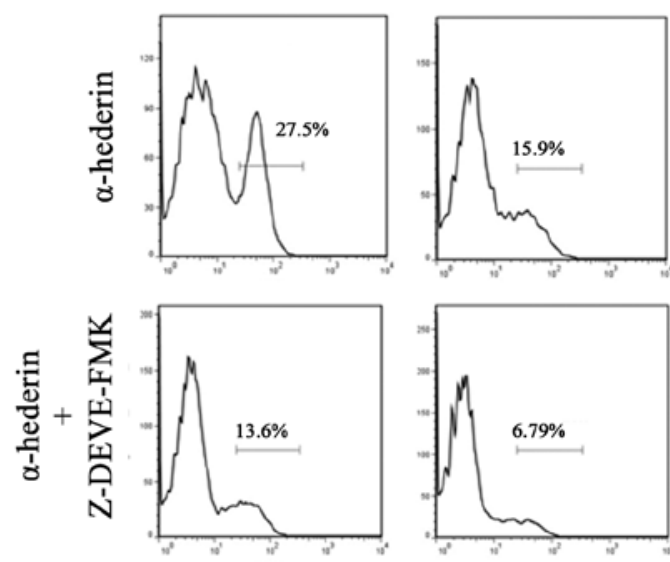

Caspase 9

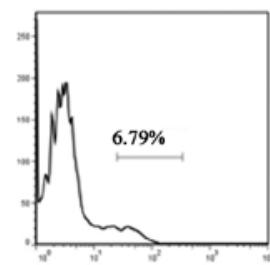

Caspase 9
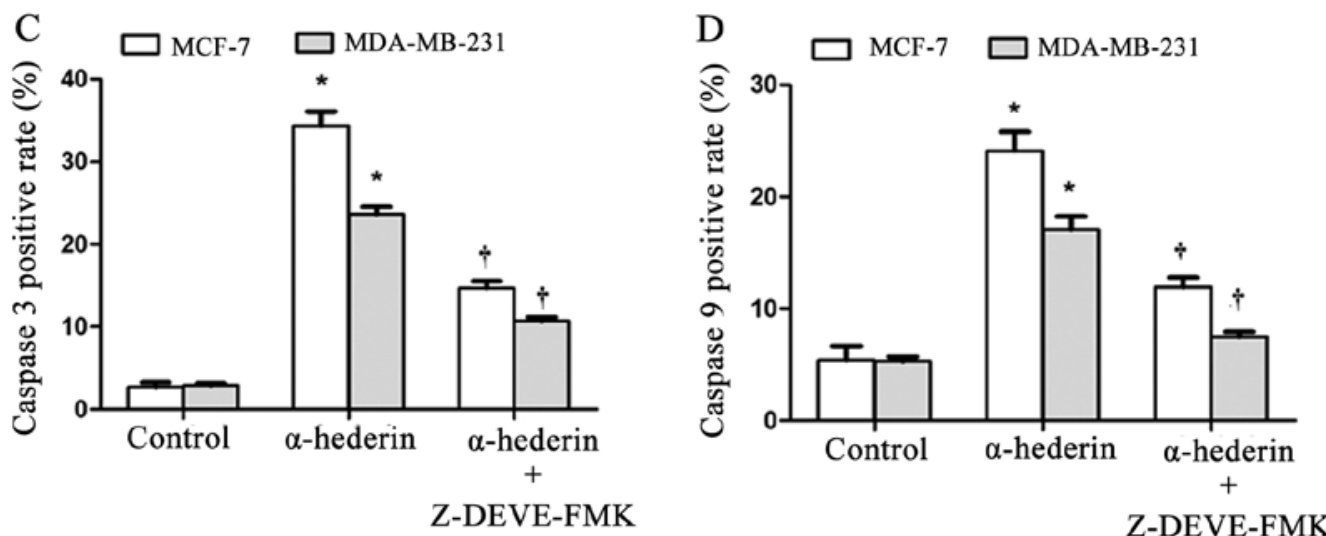

Figure 4. $\alpha$-hederin increases the activity of caspase-3 and caspase- 9 of MCF-7 and MDA-MB-231 cells. (A and B) Effect of $\alpha$-hederin on caspase-3 and caspase-9 activation. $\alpha$-hederin increased the activity of caspase- 3 and caspase- 9 in both MCF-7 and MDA-MB-231 cells. This activation could be reversed by the caspase inhibitors respectively. (C and D) Caspase-3, and caspase- 9 positive rate of cells treated with $\alpha$-hederin with/without caspase inhibitors of three independent experiments are shown in column statistics. ${ }^{*} \mathrm{p}<0.05$ vs. $\alpha$-hederin-untreated group. ${ }^{\dagger} \mathrm{p}<0.05$ vs. $\alpha$-hederin -treated alone group.

were treated with $2 \mu \mathrm{g} / \mathrm{ml} \alpha$-hederin for 6,12 and $24 \mathrm{~h}$, and then mitochondrial membrane potential was measured. After the application of $\alpha$-hederin, JC-1 fluorescence shifted from redorange to greenish yellow, which indicated the depolarization of mitochondrial membrane potential (Fig. 3A). Mitochondrial membrane potential $\Delta \Psi \mathrm{m}$ of cells treated with $\alpha$-hederin of three independent experiments are shown in column statistics (Fig. 3B).

$\alpha$-hederin regulates caspase- 3 and caspase- 9 activation. After exposure to $\alpha$-hederin $(2 \mu \mathrm{g} / \mathrm{ml})$ for $24 \mathrm{~h}$, activity of caspase-3 and caspase- 9 was increased in both MCF-7 and MDA-MB-231 cells. This activation could be reversed by the caspase inhibitors (Fig. 4A and B). Caspase-3, and caspase-9 positive rate of cells treated with $\alpha$-hederin with/without caspase inhibitors of three independent experiments are shown in column statistics (Fig. 4C and D). $\alpha$-hederin regulates the Apaf-1 and cytochrome c release. MCF-7 and MDA-MB-231 cells were treated for 2, 6, 12 or $24 \mathrm{~h}$ with $\alpha$-hederin $(2 \mu \mathrm{g} / \mathrm{ml})$ and both mitochondrial Apaf-1 and cytochrome $c$ level were detected by western blot analysis. DR $\beta-\mathrm{H}$ decreased both mitochondrial Apaf-1 and cytochrome $c$ expressions in a time-dependent manner (Fig. 5A). Expressions of mitochondrial Apaf-1 and cytochrome $c$ of cells treated with $\alpha$-hederin of three independent experiments are shown in column statistics (Fig. 5B and C).

\section{Discussion}

Our data indicate that $\alpha$-hederin from Clematis ganpiniana had strong inhibitory activity on different breast cancer cells. $\alpha$-hederin was found to induce apoptosis in both the $\mathrm{ER}^{+}$human breast cancer cell line MCF-7 and ER- breast 
A
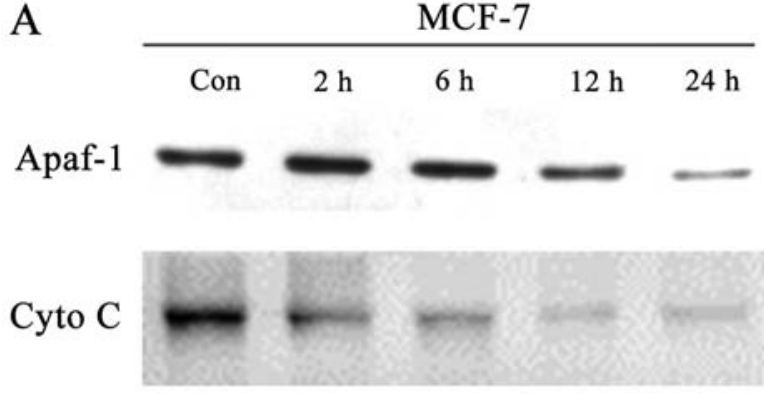

$\beta$-actin

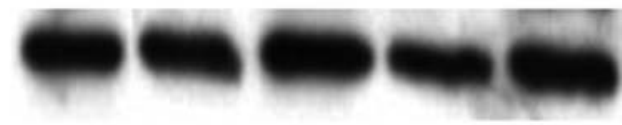

MDA-MB-231
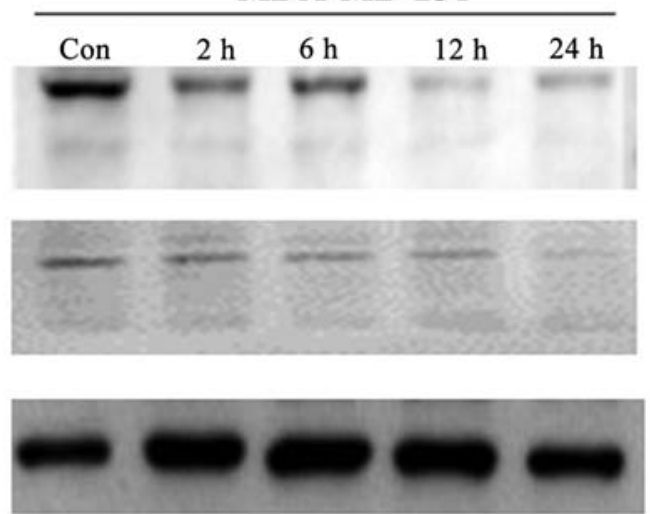
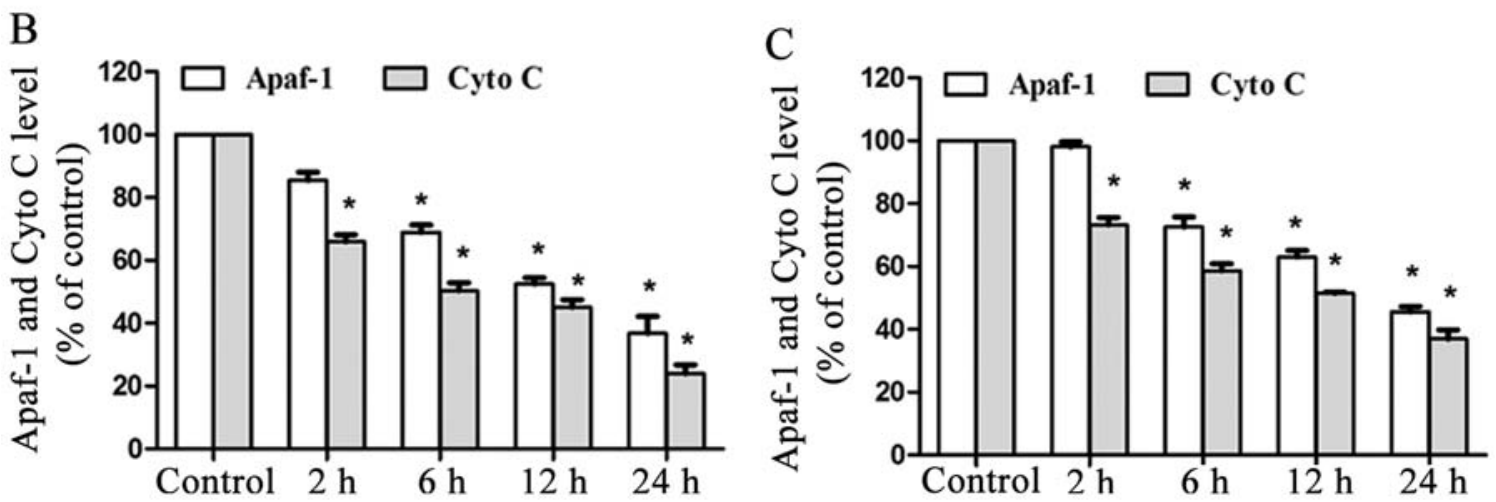

Figure 5. $\alpha$-hederin decreased mitochondrial Apaf-1 and cytochrome $c$ expressions of MCF-7 and MDA-MB-231 cells. (A) Effect of $\alpha$-hederin on Apaf-1 and cytochrome $c$ release. Cyto $\mathrm{C}$, cytochrome $c$. $\alpha$-hederin decreased the expression of both mitochondrial Apaf- 1 and cytochrome $c$ in a time-dependent manner. (B and C) Expression of mitochondrial Apaf-1 and Cytochrome $\mathrm{C}$ of cells treated with $\alpha$-hederin of three independent experiments are shown in column statistics. " $\mathrm{p}<0.05$ vs. $\alpha$-hederin-untreated group.

cancer cell line MDA-MB-231. Disruption of mitochondrial membrane potential, release of Apaf-1 and cytochrome $c$, and subsequent activation of caspase- 9 and caspase- 3 was detected in $\alpha$-hederin-treated cells.

The abstract of Clematis ganpiniana was traditionally used as a diuretic agent and an anti-inflammatory remedy by the Naxi people in China. $\alpha$-hederin extracted from Clematis ganpiniana showed cytotoxicity on breast cancer cells. Importantly, $\alpha$-hederin was found to induce apoptosis in various breast cancer cells. Apoptosis is required for proper tissue homeostasis. Defects in apoptosis signaling pathways contribute to carcinogenesis and chemoresistance. Most cancer therapeutic approaches inhibit tumors by triggering cancer cell apoptosis (26).

JC-1 staining was used to detect the membrane potential of mitochondria. The membrane potential of mitochondria in breast cancer cells was greatly reduced by $\alpha$-hederin. Apaf- 1 and cytochrome $c$ were released from the mitochondria to the cytoplasm. In $\alpha$-hederin-induced apoptosis, caspase- 3 and caspase-9 were involved. The activation of caspase family members is a critical component of the apoptotic machinery. The caspases generally consist of the upstream initiator caspases, such as caspase- $2,-8,-9$ and -10 , and the downstream effect of caspases, such as caspase-3, -6 and -7 (27). The results suggested that the caspase-dependent pathway mediated $\alpha$-hederin-induced apoptosis in breast cancer cells through the mitochondrial pathway.
Mitochondria play a central role in cancer survival and are one of the main targets for developing anticancer drugs (28). Both the extrinsic and the intrinsic pathway can converge at the mitochondrial level and trigger mitochondrial membrane permeabilization (29). Mitochondrial apoptotic pathway was reported widely for the actions of triterpenoid saponins in other human cancers including liver cancer (30-32), gastric cancer (33), esophageal cancer (34), and colorectal cancer (35). It was reported that $\alpha$-hederin from Nigella sativa induced apoptosis via mitochondrial perturbations in murine leukemia P388 cells (24). We first reported mitochondrial apoptotic activity of $\alpha$-hederin in breast cancer cells.

In conclusion, we showed $\alpha$-hederin effectively inhibited the growth and induced apoptosis of breast cancer cells. $\alpha$-hederin reduced the mitochondrial membrane potential and decreased mitochondrial Apaf- 1 and cytochrome $c$ expressions of breast cancer cells. Moreover, $\alpha$-hederin increased the activity of caspase- 3 and caspase- 9 remarkably in breast cancer cells. Consistent with these results, $\alpha$-hederin induced mitochondria-mediated apoptosis of MCF-7 and MDA-MB-231 cells. This is the first report on both chemotherapeutic effects and the mechanism of $\alpha$-hederin on human breast cancer cells, which may provide a potential option for the drug development and treatment of breast cancer. Oriental medicinal herbs are rich sources of potential cancer chemopreventive and therapeutic agents. Rigorous and systematic pre-clinical evaluations in vitro was exemplified in the 
current study to transform traditional herbal practices into evidence-based medicine.

\section{Acknowledgements}

This study was financially supported by Natural Science Foundation of China (81272916, 81202077 and 81372828), the Natural Science Foundation of Jiangsu Province (BK2011855), the key projects of Jiangsu Provincial Health Office (H201110), the Project of Jiangsu Province Traditional Chinese Medicine Bureau (LZ11084), the Six Talents Peak projects of Jiangsu Province (to Q.D.), a project Funded by the Priority Academic Program Development of Jiangsu higher Education Institutions (PAPD) and the Talent Foundation of The First Affiliated Yijishan Hospital of Wannan Medical College (YR201305).

\section{References}

1. Siegel R, Naishadham D and Jemal A: Cancer statistics, 2013. CA Cancer J Clin 63: 11-30, 2013.

2. Ribeiro JT, Macedo LT, Curigliano G, et al: Cytotoxic drugs for patients with breast cancer in the era of targeted treatment: back to the future? Ann Oncol 23: 547-555, 2012.

3. Karikas GA: Anticancer and chemopreventing natural products: some biochemical and therapeutic aspects. J BUON 15: 627-638, 2010.

4. Cragg GM and Newman DJ: Natural products: a continuing source of novel drug leads. Biochim Biophys Acta 6: 18, 2013.

5. Wang TH, Wang HS and Soong YK: Paclitaxel-induced cell death: Where the cell cycle and apoptosis come together. Cancer 88: 2619-2628, 2000.

6. Ding Q, Yang LX, Yang HW, Jiang C, Wang YF and Wang S: Cytotoxic and antibacterial triterpenoids derivatives from Clematis ganpiniana. J Ethnopharmacol 126: 382-385, 2009.

7. Podolak I, Galanty A and Sobolewska D: Saponins as cytotoxic agents: a review. Phytochem Rev 9: 425-474, 2010.

8. Augustin JM, Kuzina V, Andersen SB and Bak S: Molecular activities, biosynthesis and evolution of triterpenoid saponins. Phytochemistry 72: 435-457, 2011.

9. Bishayee A, Ahmed S, Brankov N and Perloff M: Triterpenoids as potential agents for the chemoprevention and therapy of breast cancer. Front Biosci (Landmark Ed) 16: 980-996, 2011.

10. Patlolla JMR and Rao CV: Triterpenoids for cancer prevention and treatment: Current status and future prospects. Curr Pharm Biotechnol 13: 147-155, 2012.

11. Calabrese AI: Letter: Antiviral activity of hederin. J Pharm Sci 64: VIII, 1975.

12. Gepdiremen A, Mshvildadze V, Suleyman H and Elias R: Acute anti-inflammatory activity of four saponins isolated from ivy: alpha-hederin, hederasaponin- $C$, hederacolchiside-E and hederacolchiside-F in carrageenan-induced rat paw edema. Phytomedicine 12: 440-444, 2005.

13. Gulcin I, Mshvildadze V, Gepdiremen A and Elias R: Antioxidant activity of saponins isolated from ivy: alpha-hederin, hederasaponin-C, hederacolchiside-E and hederacolchiside-F. Planta Med 70: 561-563, 2004

14. Ridoux O, Di Giorgio C, Delmas F, et al: In vitro antileishmanial activity of three saponins isolated from ivy, alpha-hederin, beta-hederin and hederacolchiside $\mathrm{A}(1)$, in association with pentamidine and amphotericin B. Phytother Res 15: 298-301, 2001.

15. Trute A, Gross J, Mutschler E and Nahrstedt A: In vitro antispasmodic compounds of the dry extract obtained from Hedera helix. Planta Med 63: 125-129, 1997.
16. Quetin-Leclercq J, Elias R, Balansard G, Bassleer R and Angenot L: Cytotoxic activity of some triterpenoid saponins. Planta Med 58: 279-281, 1992.

17. Danloy S, Quetin-Leclercq J, Coucke P, et al: Effects of alpha-hederin, a saponin extracted from Hedera helix, on cells cultured in vitro. Planta Med 60: 45-49, 1994.

18. Rooney S and Ryan MF: Effects of alpha-hederin and thymoquinone, constituents of Nigella sativa, on human cancer cell lines. Anticancer Res 25: 2199-2204, 2005.

19. Tian Z, Liu YM, Chen SB, et al: Cytotoxicity of two triterpenoids from Nigella glandulifera. Molecules 11: 693-699, 2006.

20. Yan LH, Xu LZ, Lin J, Yang SL and Feng YL: Triterpenoid saponins from the stems of Clematis parviloba. J Asian Nat Prod Res 11: 332-338, 2009.

21. Kumara SS and Huat BT: Extraction, isolation and characterisation of antitumor principle, alpha-hederin, from the seeds of Nigella sativa. Planta Med 67: 29-32, 2001.

22. Feller G, Kugel A, Moonshine D, et al: African descents are more sensitive than European descents to the antitumor compounds alpha-hederin and kalopanaxsaponin I. Planta Med 76: 1847-1851, 2010

23. Pasi S, Aligiannis N, Pratsinis H, Skaltsounis AL and Chinou IB: Biologically active triterpenoids from Cephalaria ambrosioides. Planta Med 75: 163-167, 2009.

24. Swamy SM and Huat BT: Intracellular glutathione depletion and reactive oxygen species generation are important in alpha-hederin-induced apoptosis of P388 cells. Mol Cell Biochem 245: 127-139, 2003.

25. Rooney S and Ryan MF: Modes of action of alpha-hederin and thymoquinone, active constituents of Nigella sativa, against HEp-2 cancer cells. Anticancer Res 25: 4255-4259, 2005.

26. Liu JJ, Lin M, Yu JY, Liu B and Bao JK: Targeting apoptotic and autophagic pathways for cancer therapeutics. Cancer Lett 300: 105-114, 2011.

27. Shi Y: Mechanisms of caspase activation and inhibition during apoptosis. Mol Cell 9: 459-470, 2002.

28. Dias $\mathrm{N}$ and Bailly C: Drugs targeting mitochondrial functions to control tumor cell growth. Biochem Pharmacol 70: 1-12, 2005.

29. Suen DF, Norris KL and Youle RJ: Mitochondrial dynamics and apoptosis. Genes Dev 22: 1577-1590, 2008.

30. Wang QF, Chen JC, Hsieh SJ, Cheng CC and Hsu SL: Regulation of Bcl-2 family molecules and activation of caspase cascade involved in gypenosides-induced apoptosis in human hepatoma cells. Cancer Lett 183: 169-178, 2002.

31. Wang J, Zhao XZ, Qi Q, et al: Macranthoside B, a hederagenin saponin extracted from Lonicera macranthoides and its anti-tumor activities in vitro and in vivo. Food Chem Toxicol 47: 1716-1721, 2009.

32. Park HM, Kim SJ, Kim JS and Kang HS: Reactive oxygen species mediated ginsenoside $\mathrm{Rg} 3$ - and $\mathrm{Rh} 2$-induced apoptosis in hepatoma cells through mitochondrial signaling pathways. Food Chem Toxicol 50: 2736-2741, 2012.

33. Chun J, Ha IJ and Kim YS: Antiproliferative and apoptotic activities of triterpenoid saponins from the roots of Platycodon grandiflorum and their structure-activity relationships. Planta Med 79: 639-645, 2013.

34. Mo S, Xiong H, Shu G, et al: Phaseoloideside E, a novel natural triterpenoid saponin identified from Entada phaseoloides, induces apoptosis in Ec-109 esophageal cancer cells through reactive oxygen species generation. J Pharmacol Sci 122: $163-175,2013$.

35. Wang CZ, Li XL, Wang QF, Mehendale SR, Fishbein AB, Han AH, Sun S and Yuan CS: The mitochondrial pathway is involved in American ginseng-induced apoptosis of SW-480 colon cancer cells. Oncol Rep 21: 577-584, 2009. 